\title{
AN ANALYTICAL STUDY TO EXPLORE IRON STORES IN A POPULATION OF NOWSHERA BASED ON AGE AND GENDER PERSPECTIVE
}

\author{
Hamzullah Khan ${ }^{1}$, Mohammad Basharat Khan ${ }^{2}$, Shahtaj Khan ${ }^{3}$, Saiqa Zahoor ${ }^{4}$, Anwar Khan Wazir ${ }^{5}$
}

\section{ABSTRACT:}

\section{OBJECTIVES:}

To analyze the impact of age and gender on iron stores in a population of the Nowshera region.

\section{METHODOLOGY:}

This cross sectional study was conducted in the Department of Pathology Qazi Hussain Ahmed Medical Complex Nowshera from $1^{\text {st }}$ January 2019 to $31^{\text {st }}$ March 2020. All patients were selected by convenience sampling in the Pathology department irrespective of age and gender. Both descriptive and inferential statistics were applied to analyze data by the latest SPSS version 25.

\section{RESULTS:}

Out of the total study population males were $70(27.1 \%)$ and females 188 (77.9\%) with median age 30 years. The median ferritin level was $12.8 \mathrm{ng} / \mathrm{ml}$. Out of total, 142 (55\%) of cases were with serum ferritin less than $15 \mathrm{ng} / \mathrm{ml}$. A significant $(p=0.03)$ gender based median ferritin level difference was observed with 1.5 times more probability of low iron stores in females as compared to males $(O R=1.5)$. No statistically significant difference in body iron stores exists in different age groups.

\section{CONCLUSION:}

A significant difference was noted in the iron stores in gender groups and the probability of depleted/low iron stores was higher in female gender as compared to male gender in all age groups in our population.

KEYWORDS: Gender, Iron Stores, Serum Ferritin Levels, Anemia Children

How to cite this article:

Khan H, Khan MB, Khan S, Zahoor S, Wazir AK. An Analytical Study to Explore Iron Stores in a Population of Nowshera Based on Age and Gender Perspective. J Gandhara Med Dent Sci. 2022;9(1): 33-38

https://doi.org/10.37762/jgmds.9-1.132

\section{Correspondence:}

${ }^{1}$ Hamzullah Khan Professor of Hematology, Head of Department Nowshera Medical College, Qazi Hussain Ahmed Medical Complex, Nowshera

(8) +92-334-4802902

$\searrow$ : hamzkme@gmail.com

${ }^{2}$ Assistant Professor Chemical Pathology, Nowshera

Medical College, Nowshera

${ }^{3}$ Professor of Hematology, Hayatabad Medical Complex, Peshawar

${ }^{4}$ Associate Professor of Hematology, PGMI-HMC-

Peshawar

${ }^{5}$ Professor of Physiology, Nowshera Medical College, Nowshera

\section{INTRODUCTION:}

Iron deficiency anemia (IDA) is a global issue more common in the third world countries including Pakistan. Although the prevalence of IDA is declining, still Iron deficiency continues to be the top ranking cause of anemia in children, women and adults worldwide, both in the developed and developing countries ${ }^{1}$. In Pakistan a study from Thatta Sindh, reported $63 \%$ prevalence of the Iron deficiency in women in their child gearing age ${ }^{2}$. Iron deficiency (ID) and iron deficiency anemia (IDA) can affect an individual 'es emotion, cognition, and development as iron is responsible for many enzymatic activities in the body and is related to development of normal milestone ${ }^{1}$. Serum ferritin is indirect measure of total body iron store. Exhaustion of these stores leads to Iron deficiency anemia. It is a 
predictor though not a gold standard for diagnosis of IDA $^{3}$. The determination of serum ferritin by in-vitro is done to assess body iron stores. However, it is also an acute phase reactant and is the only drawback of this indicator that would otherwise exhibit as gold standard for IDA. In adulthood ferritin concentration is directly related to the iron storage in the body. Serum ferritin concentration has the highest sensitivity and specificity to detect iron deficiency anemia. A study from Armed Force Institute of Pathology reported ferritin as gold standard for diagnosis of IDA with sensitivity of $63.5 \%$ and specificity of $38 \%$ with diagnostic accuracy of $49.4 \%$ in their target population ${ }^{4}$. In female gender, gestational age is most often associated with exhaustion of iron store and if not given iron therapy can result in morbid outcome in the form of iron deficient babies. In Pakistan the female gender in their reproductive age and children less than 5 years have been reported to be the most iron-depleted segment of our population ${ }^{5}$. Females of reproductive age and children under 5 years have been shown to be the most IDA affected population segment. Habib et al, reported IDA $47 \%$ in children aged 2-6 years, female age 17-21 years in a prevalence study covering 7491 individuals $^{6}$. Serum ferritin in the third trimester is clinically associated with the maternal outcome bad or good. There is a significant correlation between maternal serum ferritin levels when compared with parameters like birth weight, occipetofrontal circumference (OFC) and height. When maternal serum ferritin is $<15 \mathrm{ng} / \mathrm{ml}$, the babies delivered are usually mentally deficit and physically poor with low birth weight, baby height and head circumference (OFC) ${ }^{7}$. Present study was therefore designed to analyze the impact of age and gender on iron stores in a population of Nowshera.

\section{METHODOLOGY:}

This cross-sectional study was conducted in the Department of Pathology Qazi Hussain Ahmed Medical Complex Nowshera from $10^{\text {th }}$ January to $31^{\text {st }}$ December 2019. Sample size was calculated using Open-epi software. The sample size of 258 was calculated to represent the true population with absolute precision of $(5 \%)$ and confidence level of $95 \%$, taking the anticipated proportion of serum ferritin, of $45.5 \%$ from a study by Khan $\mathrm{N}$ et al published in Pakistan Armed Force Medical Journal ${ }^{8}$. Ethical approval for the survey was obtained from the Ethical Review Committee and from the Department of Research and Development, Nowshera Medical College. The inclusion criteria were all individuals irrespective of age and gender received for serum ferritin levels, in the department of Pathology. While the exclusion criteria were all candidates taking oral or IV iron therapy for their already diagnosed IDA. Two milliliters of blood was drawn from everyone, by veni-puncture under aseptic conditions. Blood in the gel bottle was stored for ferritin analysis. Blood was centrifuged. Serum Ferritin was measured by electro-chemiluminescence immunoassay using Roche Cobas E411 Chemistry Analyzer, using commercial kits of Roche diagnostics as per the instructions of the manufacturer. For calibration, we used 3 ferritin standards (corresponding to ferritin levels of 10,250 , and $1000 \mathrm{ng} / \mathrm{ml}$ ) as per the instructions of the manufacturer. Patients were categorized in three categories based on serum ferritin levels. Analysis of serum ferritin levels based on the recommendations of the $\mathrm{WHO}^{9}$.

1. IDA: less than $15 \mathrm{ng} / \mathrm{ml}$

2. Normal: $15.1-150 \mathrm{ng} / \mathrm{ml}$

3. Iron loaded: $>150 \mathrm{ng} / \mathrm{ml}$

Data was entered on SPSS version 25. The normality of data was assessed using the Shapero-wilk test. The quantitative variables were presented as mean with SD or median and range depending on the distribution of data. Categorical variables were represented with percentages. Mann Whitney U test was applied to show the difference of ferritin in age and gender groups. Chi square test was used to show the association of iron stores in gender and age groups.

\section{RESULTS:}

The total number of patients was 258. Out of the total sampling, $70(27.1 \%)$ were males and $188(77.9 \%)$ females. The age and levels of ferritin distribution was in a skewed pattern (p-0.0001, Shapiro-wilk test). The median ferritin level was $12.8 \mathrm{ng} / \mathrm{ml}$, ranging from minimum of 1.86 to maximum of $2000 \mathrm{ng} / \mathrm{ml}$ (Table 1). Out of total, $142(55 \%)$ of cases had serum ferritin $<15 \mathrm{ng} / \mathrm{ml}$ (Table 1 ). The median level of the serum ferritin in male gender was significantly higher than female patients with $\mathrm{p}$-value of 0.03 (Table 2). We observed an increase in iron stores in male gender and depleted ferritin levels were noted in the female gender (p-0.017) (Table 3). Furthermore, a risk of two times was noted to have low iron stores in female gender as compared to male gender (OR-2, 95\%CI: 1.12-3.55) (Table 4). Likewise, the distribution of iron stores in different age groups is mentioned (Table 5) with a nonsignificant $\mathrm{p}$-value (p-0.994). 


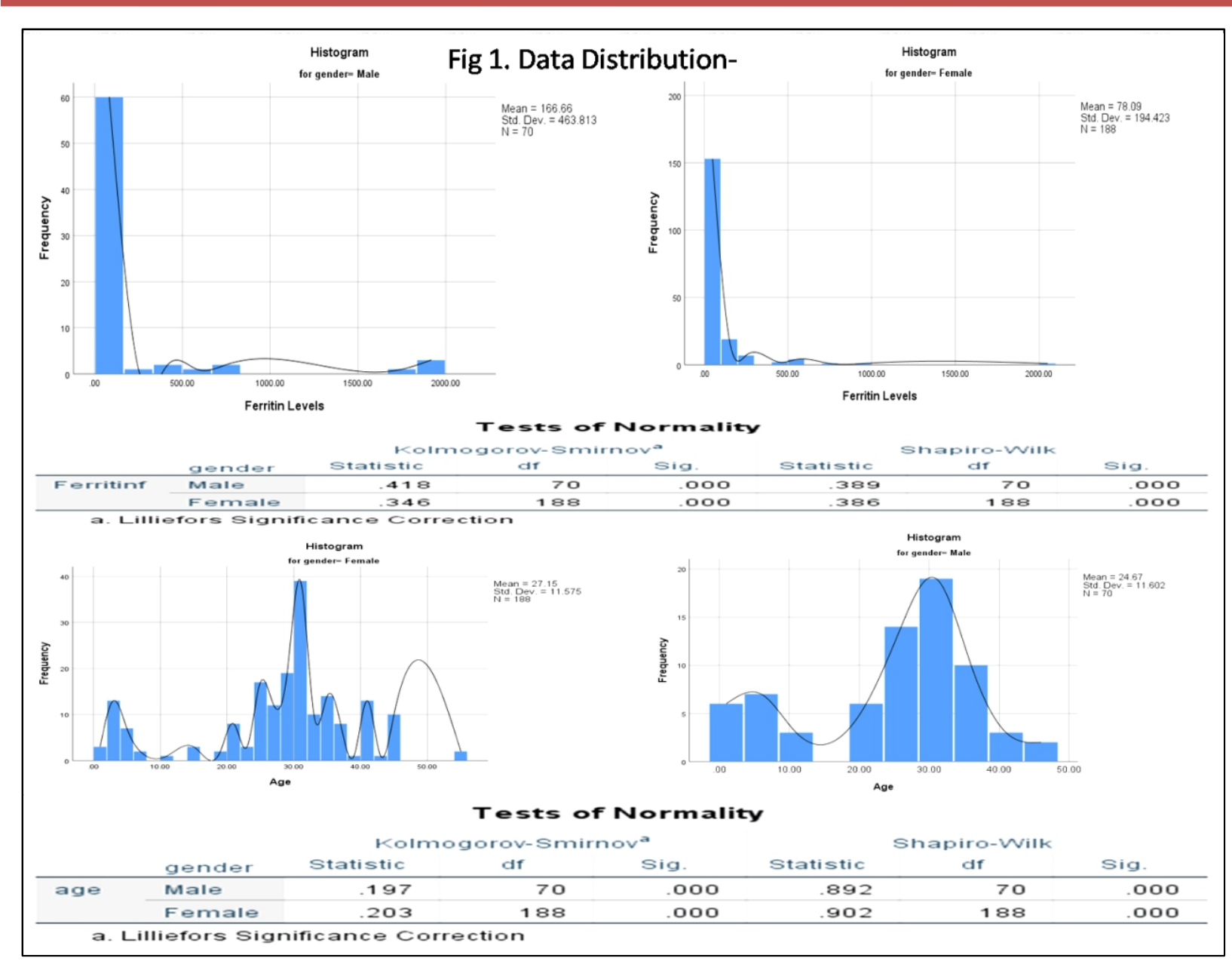

Figure 1: Data Distribution

Table 1: Categories of Iron Stores in Patients Based on Serum Ferritin

\begin{tabular}{|l|c|c|c|}
\hline & Frequency & Percent & Cumulative Percent \\
\hline Less than $15 \mathrm{ng} / \mathrm{ml}$ (IDA) & 142 & 55.0 & 55.0 \\
\hline $15.1-150 \mathrm{ng} / \mathrm{ml}$ (Normal) & 81 & 31.4 & 86.4 \\
\hline$>150 \mathrm{ng} / \mathrm{ml}$ (Loaded) & 35 & 13.6 & 100.0 \\
\hline Total & 258 & 100.0 & \\
\hline
\end{tabular}

Table 2: Non-Parametric Test (Mann Whitney U Test) Showing Distribution of Iron Stores in Gender Groups

\begin{tabular}{|l|l|c|c|c|}
\hline \multicolumn{2}{|c|}{ Gender } & $\begin{array}{c}\text { Number of } \\
\text { Patients }\end{array}$ & Median & Mann Whitney U Test \\
\hline \multirow{3}{*}{ Ferritin } & Male & 70 & 12.80 & 0.032 \\
\cline { 2 - 4 } & Female & 188 & 10.60 & \\
\cline { 2 - 4 } & Female & 188 & 25.00 & \\
\hline
\end{tabular}

Table 3: Chi Square Test to Show the Association of Iron Stores in Gender Groups

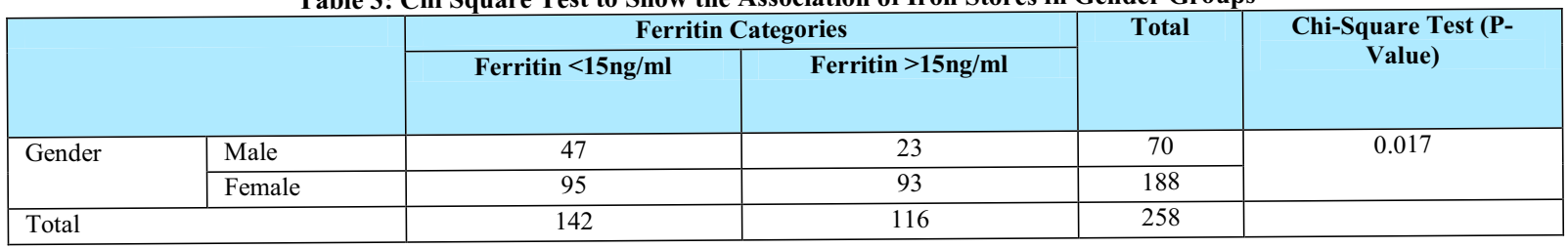




\begin{tabular}{|c|c|c|c|}
\hline & \multirow[t]{2}{*}{ Value } & \multicolumn{2}{|c|}{ 95\% Confidence Interval } \\
\hline & & Lower & Upper \\
\hline Odds Ratio for Gender (Male/Female) & 2.00 & 1.12 & 3.55 \\
\hline For Cohort Ferritin Category $=$ Ferritin $<15 \mathrm{ng} / \mathrm{ml}$ & 1.32 & 1.07 & 1.65 \\
\hline For Cohort Ferritin Category $=$ Ferritin $>15 \mathrm{ng} / \mathrm{ml}$ & 0.66 & 0.46 & 0.95 \\
\hline $\mathrm{N}$ of Valid Cases & \multicolumn{3}{|c|}{258} \\
\hline
\end{tabular}

\begin{tabular}{|c|c|c|c|c|c|}
\hline & & \multicolumn{2}{|c|}{ Ferritin Categories } & \multirow[t]{2}{*}{ Total } & \multirow[t]{2}{*}{ Chi-Square Test (P-Value) } \\
\hline & & $\begin{array}{c}\text { Ferritin Less Than } \\
15 \mathrm{ng} / \mathrm{ml}\end{array}$ & $\begin{array}{c}\text { Ferritin More Than } \\
15 \mathrm{ng} / \mathrm{ml}\end{array}$ & & \\
\hline \multirow[t]{4}{*}{ Age Categories } & $<5$ Year & 17 & 14 & 31 & \multirow[t]{4}{*}{0.994} \\
\hline & 6-18 Year & 8 & 7 & 15 & \\
\hline & 19-35 Year & 94 & 75 & 169 & \\
\hline & 26-55 Year & 23 & 20 & 43 & \\
\hline Total & & 142 & 116 & 258 & \\
\hline
\end{tabular}

\section{DISCUSSION:}

Serum Ferritin level estimation is a cost effective and indirect measurement of iron stores in the body. We observed a skewed distribution of ferritin levels in our population ranging from $1.86 \mathrm{ng} / \mathrm{ml}$ (minimum) to $2000 \mathrm{ng} / \mathrm{ml}$ (maximum). Likewise 142 $(55 \%)$ of total cases had serum ferritin less than $15 \mathrm{ng} / \mathrm{ml}$. The median ferritin level was $12.8 \mathrm{ng} / \mathrm{ml}$. A study reported showed that more than 505 of their target population were having iron stores less than $20 \mathrm{ng} / \mathrm{ml},{ }^{10}$ that were in concordance with our findings. The median values of serum ferritin of the male gender $(12.8 \mathrm{ng} / \mathrm{ml})$ were significantly higher than female gender $(10.6 \mathrm{ng} / \mathrm{ml}+11) \quad(\mathrm{p}-0.004)$. Abuaisha $\mathrm{M}$ et $\mathrm{al}^{11}$, reported the prevalence of iron deficiency in $57.5 \%$ females and $7.6 \%$ in males with $192(87.67 \%)$ cases with serum ferritin less than $15 \mathrm{ng} / \mathrm{ml}$. Another study published in Reprod Health reported ferritin less than $13 \mathrm{ng} / \mathrm{ml}$ in $41 \%$ in antenatal woment ${ }^{12-14}$. They also suggested that it would be worthwhile to assess the ferritin levels in antenatal visits amongst the anemic patients. The difference in Means $\_$SD of serum ferritin in our target population for male gender (205.66ng/ml_587.5) was statistically significant with the Mean + SD ferritin of female gender $\left(75.38 \mathrm{ng} / \mathrm{ml} \_217.32\right)$ with $\mathrm{p}$-value of 0.004 . Apparently, the low levels of the ferritin values in women have been reported representing iron deficiency in female gender. Reference ranges need to be evaluated based on gender of the specific geographical location and history of iron intake and menstrual and gestational history ${ }^{15,16}$.We also observed the probability of iron deficiency was 1.5 times more in female gender as compared to male gender $(\mathrm{OR}=1.5)$. Another regression analysis from Jordan reported that Ferritin deficiency was observed in $55.8 \%$ of the female study population, ${ }^{15,17}$ that matches our findings $(58.9 \%)$. Similarly, their regression analysis showed female gender 2.5 times more at risk $(\mathrm{p}<0.05, \mathrm{OR}=2.5)$ of low iron stores as compared to their counterparts. In present study we did not find a significant difference in iron stores in different four age groups as mentioned in our study. Our study correlated with other researchers however a study from Rawalpindi suggests serum ferritin as the best indicator and predictor of IDA in children/pediatric groups irrespective of gender ${ }^{18}$.

\section{CONCLUSION:}

It is concluded that serum ferritin is a good predictor for diagnosis of iron deficiency anemia. Female gender has more probability of acquiring iron deficiency anemia and low iron stores. A high proportion of sampling $142(55 \%)$ had serum ferritin levels less than $15 \mathrm{ng} / \mathrm{ml}$. It is recommended that as IDA is more common in female gender therefore all the females attending the antenatal care services in tertiary and secondary care hospital with $\mathrm{Hb} \%$ less than $11 \mathrm{~g} / \mathrm{dl}$ must be screened for serum ferritin levels and remedial action may be taken well in time to combat iron deficiency in pregnancy especially in third trimester to avoid the fetal thirst for iron and to avoid neonatal morbidities and mortalities associated with IDA.

CONFLICT OF INTEREST: None

FUNDING SOURCES: None 


\section{REFERENCES:}

1. Camaschella C. Iron-deficiency anemia. N Engl J Med. 2015;372:1832-43.

2. Ali SA, Abbasi Z, Shahid B, Moin G, Hambidge KM, Krebs NF, et al. Prevalence and determinants of anemia among women of reproductive age in Thatta Pakistan: findings from a cross-sectional study. PLoS One. 2020;15(9):e0239320.

3. Babaei M, Shafiei S, Bijani A, Heidari B, Hosseyni SR, Vakili Sadeghi M. Ability of serum ferritin to diagnose iron deficiency anemia in an elderly cohort. Rev Bras Hematol Hemoter. 2017;39(3):223-8.

4. Asif N, Ijaz A, Rafi T, Haroon ZH, Bashir S, Ayyub M. Diagnostic accuracy of serum iron and total iron binding capacity (TIBC) in iron deficiency state. J Coll Physicians Surg Pak. 2016;26(12):958-61.

5. Akhtar S, Ahmed A, Ahmad A, Ali Z, Riaz M, Ismail $\mathrm{T}$. Iron status of the Pakistani population-current issues and strategies. Asia Pac J Clin Nutr. 2013;22(3):340-7.

6. Habib MA, Black K, Soofi SB, Hussain I, Bhatti Z, Bhutta ZA, et al. Prevalence and predictors of iron deficiency anemia in children under five years of age in Pakistan: a secondary analysis of National Nutrition Survey Data 2011-2012. PLoS One. 2016;11(5):e0155051.

7. Smith ER, Shankar AH, Wu LS, Aboud S, Adu-Afarwuah S, Ali H, et al. Modifiers of the effect of maternal multiple micronutrient supplementation on stillbirth, birth outcomes, and infant mortality: a meta-analysis of individual patient data from 17 randomised trials in low-income and middle-income countries. Lancet Global Health. 2017;5(11):e1090-1100.

8. Khan N, Altaf C, Malik H, Sajjad Z, Khurshid A, Khadim M. Diagnostic accuracy of reticulocyte hemoglobin equivalent (RETHE) in detecting iron deficiency anemia keeping serum ferritin as gold standard. Pak Armed Forces Med J. 2019;69(5):1010-4.

9. World Health Organization. Worldwide Prevalence of Anemia 1993-2005: WHO Global Database on Anemia. Benoist B, McLean E, Egli I, Cogeswell M, editors. Geneva: World Health Organization; 2020.

10. Soofi S, Khan GN, Sadiq K, Ariff S, Habib A, Kureishy $\mathrm{S}$, et al. Prevalence and possible factors associated with anaemia, and vitamin B-12 and folate deficiencies in women of reproductive age in Pakistan: analysis of national-level secondary survey data. BMJ Open. 2017;7(12):e018007.

11. Abuaisha M, Itani H, El-Masri R, Antoun J. Prevalence of Iron Deficiency (ID) without anemia in the general population presenting to primary care clinics: a crosssectional study. Postgrad Med. 2020;22:16.

12. Mistry R, Jones AD, Pednekar MS, Dhumal G, Dasika A, Kulkarni U, et al. Antenatal tobacco use and iron deficiency anemia: integrating tobacco control into antenatal care in urban India. Reprod Health. 2018;15(1):72-6.

13. Fonseca C, Araújo M, Moniz P, Marques F, Araújo I, Costa L, et al. Prevalence and prognostic impact of anemia and iron deficiency in patients hospitalized in an internal medicine ward: the PRO-IRON study. Eur J Haematol. 2017;99(6):505-13.

14. Means RT. Iron deficiency and iron deficiency anemia: implications and impact in pregnancy, fetal development, and early childhood parameters. Nutrients. 2020;12(2):447.

15. Shattnawi KK, Alomari MA, Sheyab NA, Salameh AB. The relationship between plasma ferritin levels and body mass index among adolescents. Sci Rep. 2018;8:15307.

16. Donahue M, Berti P, Siekmans K, Tugirimana PL, Boy E. Prevalence of iron deficiency and iron deficiency anemia in the northern and southern provinces of Rwanda. Food Nutr Bull. 2017;38(4):55463.

17. Epstein D, Borohovitz A, Merdler I, Furman M, Atalli E, Sorkin A, et al. Prevalence of iron deficiency and iron deficiency anemia in strenuously training male army recruits. Acta Haematol. 2018;139(3):141-7.

18. Kazmi A, Mansoor R, Almani MIK, Zafar H. Estimation of serum ferritin level to detect iron deficiency anemia in children less than 5 years of age. J Islamabad Med Dent Coll. 2017;6(4):259-62. 


\section{CONTRIBUTORS}

1. Hamzullah Khan - Concept \& Design; Data Acquisition; Data Analysis/Interpretation; Drafting Manuscript ; Supervision; Final Approval

2. Mohammad Basharat Khan - Concept \& Design; Critical Revision; Supervision; Final Approval

3. Shahtaj Khan - Concept \& Design; Data Analysis/Interpretation; Critical Revision

4. Saiqa Zahoor - Concept \& Design; Critical Revision; Supervision; Final Approval

5. Anwar Khan Wazir - Concept \& Design; Data Acquisition; Critical Revision; Supervision; Final Approval

LICENSE: JGMDS publishes its articles under a Creative Commons Attribution Non-Commercial Share-Alike license (CC-BY-NC-SA 4.0) COPYRIGHTS: Authors retain the rights without any restrictions to freely download, print, share and disseminate the article for any lawful purpose. It includes scholarly networks such as Research Gate, Google Scholar, LinkedIn, Academia.edu, Twitter, and other academic or professional networking sites. 